\title{
Occupant friendly seismic retrofit by concrete plates*
}

\author{
Mehmet BARAN ${ }^{\dagger 1}$, Merve AKTAS ${ }^{2}$ \\ $\left({ }^{I}\right.$ Department of Civil Engineering, Engineering and Natural Sciences Faculty, Yildirim Beyazit University, 06110, Ulus, Ankara, Turkey) \\ ('Institute of Science, Kirikkale University, Yahsihan 71450, Kirikkale, Turkey) \\ †E-mail: mbaran@ybu.edu.tr
}

Received May 14, 2012; Revision accepted Feb. 21, 2013; Crosschecked Oct. 12, 2013

\begin{abstract}
An innovative occupant friendly retrofitting technique has been developed for reinforced concrete (RC) building structures with hollow brick infill walls used as partition walls which constitute the major portion of the existing building stock in Turkey. The idea is to convert the existing hollow brick infill wall into a load carrying system acting as a cast-in-place RC wall by reinforcing it with relatively thin concrete plates bonded to the mortar coated infill wall by use of tile adhesive and fixed by $\Phi 6$ ( $6 \mathrm{~mm}$ diameter) bolts. Test parameters were the shape and thickness of the plates, presence of reinforcement in plates, number and arrangement of $\Phi 6$ bolts. It was observed that lateral strength, stiffness, energy dissipation capacity, and ductility of the strengthened infill walls were improved and behaviour was enhanced by the proposed technique. Plates with two different basic shapes were used to strengthen the test specimens.
\end{abstract}

Key words: Reinforced concrete (RC), Strengthening, Concrete plate, Lateral strength, Stiffness, Hollow brick infills, Reversed-cyclic lateral loads doi:10.1631/jzus.A1200324

Document code: A

CLC number: TU502

\section{Introduction}

Turkey is located in a very high seismic zone. In addition, poor construction quality, wrong detailing, and structural mistakes have caused enormous loss of lives and properties. Therefore, seismic rehabilitation has been a major topic for civil engineers in Turkey.

Repair of damaged structures after earthquakes has been an important area. Turkey has gained significant experience on repair of structures (Canbay et al., 2003; Sonuvar et al., 2004; Turk et al., 2006). There is, however, great building stock waiting for strengthening before a major earthquake strikes. Because of this huge demand to strengthen structures, researchers have been continuously working on the strengthening of structures while in use. Related studies have focused currently on occupant friendly

\footnotetext{
${ }^{*}$ Project (No. BAP 2011/76) supported by the Scientific Research Projects Coordination Unit of Kirikkale University, Turkey

(C) Zhejiang University and Springer-Verlag Berlin Heidelberg 2013
}

strengthening techniques.

Many studies on more feasible, rapid, and easy techniques that do not require evacuating the structure, have been successfully implemented in Turkey. Studies on strengthening of masonry infilled walls with carbon fiber reinforced polymer (CFRP) (Antoniades et al., 2005; Erdem et al., 2006; Binici and Özcebe, 2006; Altın et al., 2008), shotcrete with mesh reinforcement (Kahn, 1984; Alcocer et al., 1996; Acun and Sucuoğlu, 2005; Korkmaz et al., 2010), steel plates (Taghdi et al., 2000a; 2000b; Farooq et al., 2006), steel fiber reinforced mortar (Sevil et al., 2011) and prefabricated panel infills (Frosch et al., 1996a; 1996b; Frosch, 1996; 1999; Baran and Tankut, 2011a; $2011 \mathrm{~b}$ ) can be found. In addition, innovative materials such as textiles (Papanicolaou et al., 2011), ferrocement (Topçu et al., 2005; Amanat et al., 2007), epoxy and mortar injection (ElGawady et al., 2004) have also been used in strengthening of the hollow brick infill walls. These studies have been completed and offer different alternatives for seismic 
strengthening. Among them, CFRP is the most popular technique. However, CFRP is an expensive import material, which shows brittle behaviour and requires qualified workmanship during application. In addition, prefabricated panel is also a popular technique but has to be attached by means of costly epoxy materials, which leads strengthening costs to take a significant portion among the overall costs.

In developing this method, it is important to use cheap domestic materials while using the strengthening methods developed. When the number of buildings that have to be strengthened is concerned, this approach becomes significantly important in terms of the country's economy.

The object of this study is to develop an economical and new method which will provide strengthening of buildings without evacuating the structure, and to prove experimentally that this new method provides the necessary strength and lateral rigidity to the structure. This method is based on bonding relatively thin precast plates on to the mortar coated hollow brick infills by means of cheap domestic tile adhesive.

In this study, a total of 13 mortar coated hollow brick infill walls, including one reference specimen, were tested under reversed cyclic lateral loads until failure. Test specimens were strengthened by relatively thin plates with two basic shapes, namely rectangular and strip. In reality, one single piece of concrete plate covering the whole infill wall would definitely be unmanageable, too large to go through doors and too heavy to be carried manually. It would have to consist of individual plates of manageable size and weight, and has to be assembled on the wall by connecting the plates together. The plates would readily be available and easily transported and assembled in place at the site. Test parameters, i.e., shape and thickness of the plates, presence of reinforcement in plates, number and arrangement of $\Phi 6(6 \mathrm{~mm} \mathrm{di}-$ ameter) bolts, were obtained.

\section{Experimental}

\subsection{Test specimens}

Mortar coated hollow brick infill walls with dimensions of $1200 \mathrm{~mm} \times 1500 \mathrm{~mm}(1 / 2$ scaled $)$ were used as test units. Hollow bricks with dimensions of $85 \mathrm{~mm} \times 190 \mathrm{~mm} \times 190 \mathrm{~mm}$ were bonded to form the units with their hollows being horizontal and mortar coated at both faces by ordinary cement-lime-sand mixture. Thickness of the mortar coat was approximately $15 \mathrm{~mm}$. In every line, the last hollow brick was put with its hollow being vertical. Precast plates were prepared with normal strength concrete and wooden moulds. Since all test specimens and plates were not mould on the same day, mortar and plate concrete compressive strengths vary.

Ordinary cement-lime mortar was used for the mortar coat, reflecting the usual practice. Ordinary workmanship was intentionally employed in wall construction and mortar coat application. All specimens were strengthened with $20 \mathrm{~mm} / 25 \mathrm{~mm}$ thick plates bonded on to the mortar coat by means of $2-$ $3 \mathrm{~mm}$ thick tile adhesive and fixed by means of $\Phi 6$ bolts. Fig. 1 shows the dimension and details of test specimens.

Test specimen designations start with the letter $\mathrm{R}$ or $\mathrm{S}$, indicating the geometry of the strengthening plate, namely rectangular or strip, followed by $\mathrm{P}$ to designate plate. After the first two letters, the third letter $\mathrm{R}$, if present, designates that the plate is reinforced. If the letter $\mathrm{R}$ is not present, then the plate is plain concrete. The two letters after the first dash, namely MA, HA, and FA, designate minimum, half and full anchorages respectively. The number after the second dash designates the thickness of the plate in centimeters. Lastly, the letter D after this number, if present, designates double meaning plate application on both sides of the infill.

\subsection{Material properties}

Hollow bricks, sold widely in the market, were used in the test specimens. Compressive strength of the hollow bricks were calculated as $12.0 \mathrm{MPa}$ in the direction parallel to the hollows, $2.8 \mathrm{MPa}$ in the short direction perpendicular to the hollows, and $3.2 \mathrm{MPa}$ in the long direction perpendicular to the hollows, using the net area. Hollow bricks were bonded together and mortar coated at both faces by ordinary cement-lime-sand mixture in a ratio of $1: 2: 10$ by weight. Precast plates were bonded on to the mortar coat by an ordinary tile adhesive brand. In the catalogue, the starting and final bonding strengths of this adhesive is given as 0.5 and 1.0 MPa, respectively. For reinforcing some of the plates, a special welded wire mesh type, with $\Phi 2.0$ longitudinal bars with a 

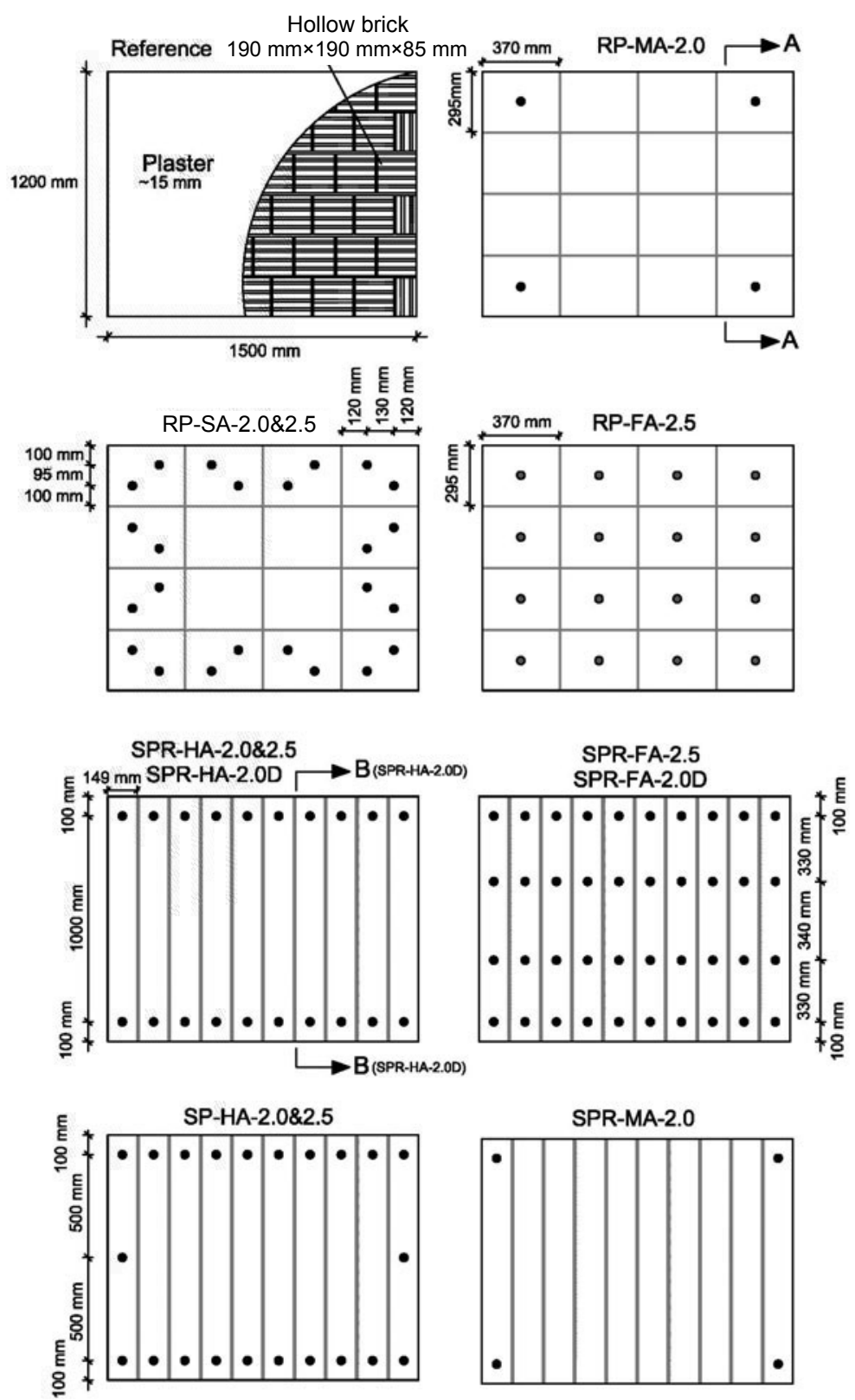

Fig. 1 Dimensions and details of strengthened test specimens

spacing of $25 \mathrm{~mm}$ for both directions was used. Regarding plate attachment, standard production $\Phi 6$ threaded bolts were used, with average yield and ultimate strengths of 625.2 and $696.1 \mathrm{MPa}$, respectively. Properties of test specimens are given in Table 1 and different reinforcement arrangements of plates are illustrated in Fig. 2.

\subsection{Loading-supporting system and instrumenta- tion}

In Fig. 3, the general view of the test set-up is given. As shown in this figure, tests were performed in front of a reaction wall. Test specimens were placed in a rigid steel frame which has pin connections at all four sides and is subjected to reversed cyclic lateral loading resembling seismic effects. During the tests, a two-phase loading pattern was applied. In the first phase, lateral loading was increased up to $40 \mathrm{kN}$ with regular $5 \mathrm{kN}$ increments and beyond that with $10 \mathrm{kN}$ increments, where the deformation controlled loading was performed with increasing displacement cycles in the second phase.

All deformations were measured by linear variable displacement transducers (LVDTs) (Fig. 3). 
Table 1 Properties of test specimens

\begin{tabular}{lccccc}
\hline $\begin{array}{c}\text { Test } \\
\text { specimen }\end{array}$ & $\begin{array}{c}\text { Plate thickness } \\
(\mathrm{mm})\end{array}$ & $\begin{array}{c}\text { Plate } \\
\text { reinforcement }\end{array}$ & $\begin{array}{c}\text { Number } \\
\text { of } \Phi 6 \text { bolts }\end{array}$ & $\begin{array}{c}\text { Brick bonding mortar and } \\
\text { mortar coat strength (MPa) }\end{array}$ & $\begin{array}{c}\text { Plate strength } \\
(\mathrm{MPa})\end{array}$ \\
\hline Reference & - & - & - & 1.7 & - \\
RP-MA-2.0 & 20 & - & 4 & 1.7 & 21.0 \\
RP-SA-2.0 & 20 & - & 24 & 2.3 & 12.9 \\
RP-SA-2.5 & 25 & - & 24 & 2.4 & 17.2 \\
RP-FA-2.5 & 25 & - & 16 & 2.5 & 21.0 \\
SP-HA-2.0 & 20 & - & 22 & 2.5 & 12.9 \\
SPR-MA-2.0 & 20 & $\Phi 2 / 25$ & 4 & 2.2 & 14.6 \\
SPR-HA-2.0 & 20 & $\Phi 2 / 25+2-\Phi 5$ & 20 & 1.8 & 25.8 \\
SP-HA-2.5 & 25 & - & 22 & 1.8 & 17.2 \\
SPR-HA-2.5 & 25 & $\Phi 2 / 25$ & 20 & 2.5 & 23.4 \\
SPR-FA-2.5 & 25 & $\Phi 2 / 25+2-\Phi 5$ & 40 & 2.6 & 23.6 \\
SPR-HA-2.0D & 20 & $\Phi 2 / 25$ & 20 & 1.8 & 22.1 \\
SPR-FA-2.0D & 20 & $\Phi 2 / 25$ & 40 & 1.7 & 23.7 \\
\hline
\end{tabular}

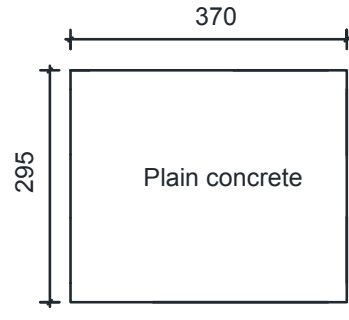

Rectangular plate

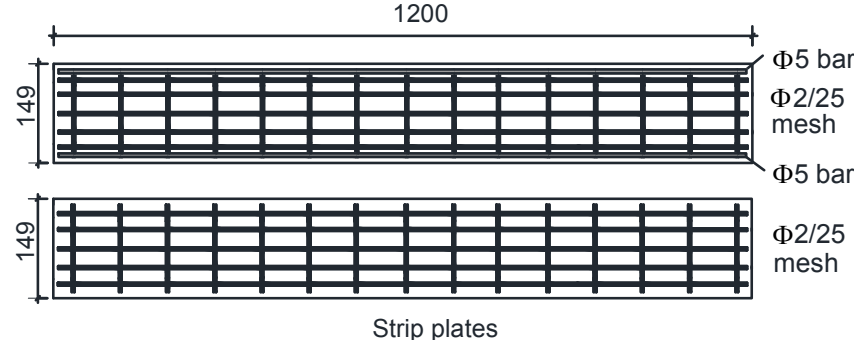

Strip plates

Fig. 2 Reinforcement arrangements of precast plates (unit: $\mathbf{m m}$ )

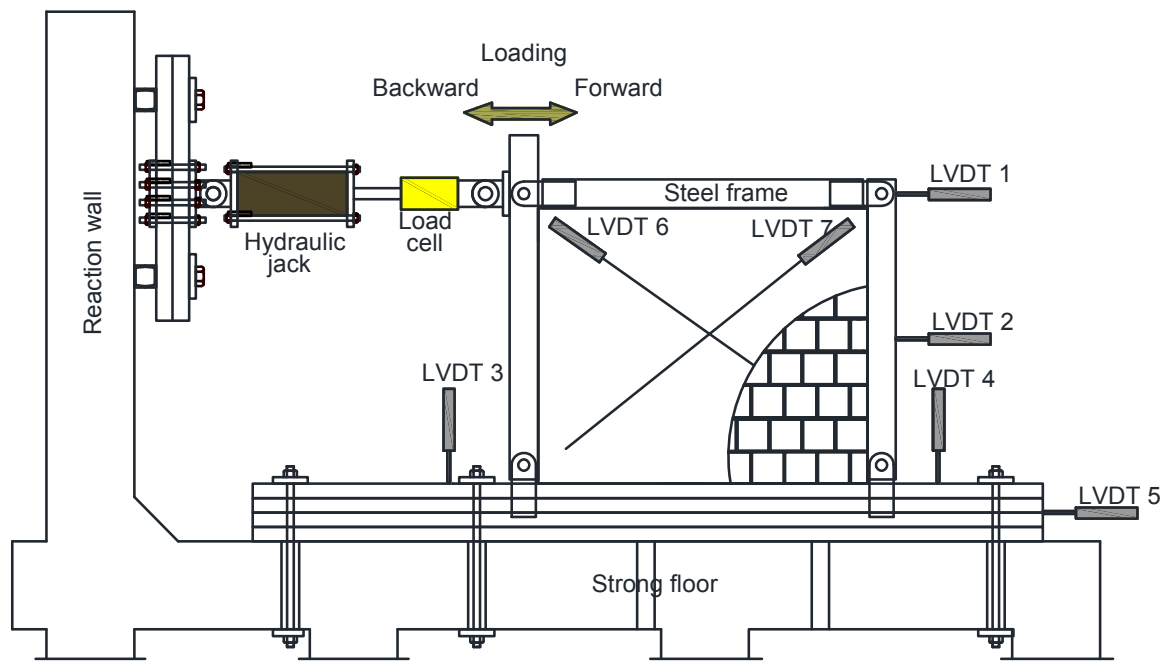

Fig. 3 Loading-supporting system and instrumentation

Sway displacements were measured by two LVDTs at the beam level. Infill wall shear deformations were determined on the basis of LVDTs along the diagonals. During the tests, all data were recorded electronically. 


\section{Results}

One unstrengthened and 12 mortar coated hollow brick infill wall specimens strengthened by bonding precast plates on to the mortar coat and fixed by $\Phi 6$ bolts, were tested under reversed cyclic lateral loading simulating earthquake effect till failure. In the test of the reference specimen, rather rigid and linearly elastic behaviour was observed at the initial stages. Up to the ninth forward cycle, only local crashes at the loaded corners were observed. On the tenth forward cycle, a sudden diagonal crack occurred together with the corner crashes at a lateral load level of $53.4 \mathrm{kN}$ and at a steel test frame's beam level displacement of $52.3 \mathrm{~mm}$. In the next few cycles, typical infill behaviour characterized by rapid strength degradation and rapid stiffness degradation was observed upon diagonal cracking. This expected behaviour was concluded by a typical failure accompanied by excessive permanent sway deformations. Lateral load-beam level displacement graph and a photograph at the end of the test of reference is given in Fig. 4.
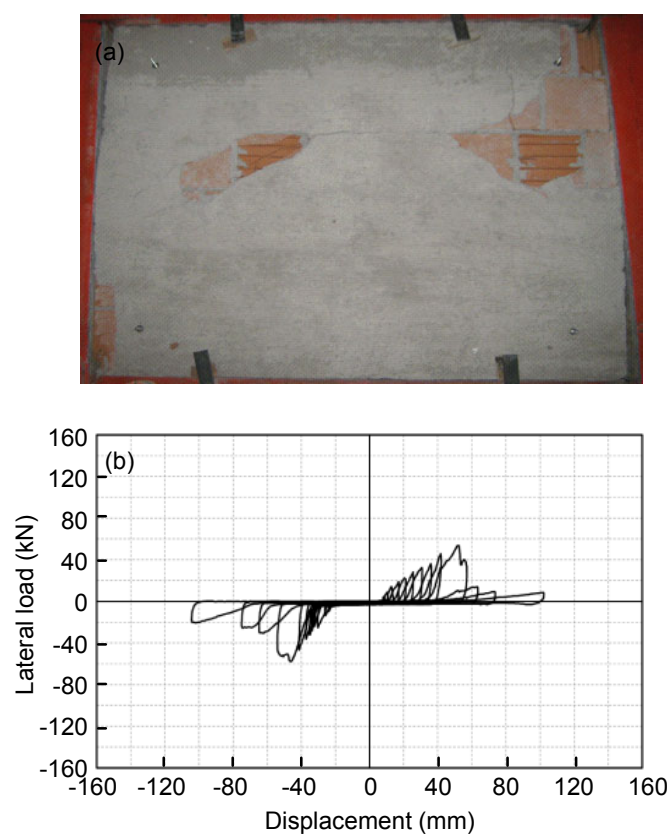

Fig. 4 Photograph after test (a) and load-displacement graph (b) of reference

Test specimens RP-MA-2.0 and RP-SA-2.0 were strengthened by $20 \mathrm{~mm}$ thick rectangular plain concrete plates. In the test of RP-MA-2.0, cracking were observed in between the plate joints in the first cycle and only local crashes were observed on all four corner plates up to the twelfth forward cycle. In the twelfth backward cycle, a horizontal crack occurred in between the plate joints that divided the infill wall into two at a load of $82.0 \mathrm{kN}$ and at a displacement of $42.5 \mathrm{~mm}$. In the test of RP-SA-2.0, up to the fourteenth forward cycle, corner plates locally crushed in the direction of loading until a sudden horizontal plate joint crack occurred. At this instant, the lateral load capacity was $78.7 \mathrm{kN}$ at a displacement of $47.2 \mathrm{~mm}$. Towards the end of both tests, upon some corner plates' leaving the mortar coat, hollow bricks fell off and the tests were terminated. Load-displacement graphs and photographs at the end of the tests of RP-MA-2.0 and RP-SA-2.0 are given in Fig. 5 and Fig. 6, respectively.

Test specimens RP-SA-2.5 and RP-FA-2.5 were strengthened by $25 \mathrm{~mm}$ thick rectangular plain concrete plates. Specimen RP-SA-2.5 reached a lateral load capacity of $80.7 \mathrm{kN}$ at a displacement level of $40.6 \mathrm{~mm}$ at the thirteenth forward cycle, whereas these values were $80.7 \mathrm{kN}$ and $41.0 \mathrm{~mm}$ for specimen RP-FA-2.5 at the thirteenth backward cycle. As in the cases of previous specimen pairs, almost nothing occurred except for the local crushes at all four corner plates until the thirteenth cycle for both specimens. But it should be noted that only horizontal cracks occurred in between the plate joints of specimen RP-SA-2.5, whereas both horizontal and vertical cracks differentiated all the plates from each other in the case of RP-FA-2.5. Towards the end in both tests, plates separated from each other. Load-displacement graphs and photographs at the end of the tests of RP-SA-2.5 and RP-FA-2.5 are given in Fig. 7 and Fig. 8, respectively.

Test specimens SP-HA-2.0 and SP-HA-2.5 were strengthened by $20 \mathrm{~mm}$ thick rectangular plain concrete plates and reached lateral load carrying capacities of 90.0 and $99.6 \mathrm{kN}$ at displacement levels of 46.3 and $76.2 \mathrm{~mm}$ in the thirteenth and fourteenth forward cycles, respectively. In the proceeding cycles, only crashes were observed at the corner plates of the loading direction whereas diagonal cracks in addition to these crashes appeared in both tests near the twelfth cycle in both tests. Since they were not reinforced, corner plates especially could not resist loads effectively and they were crushed. In the last cycle 

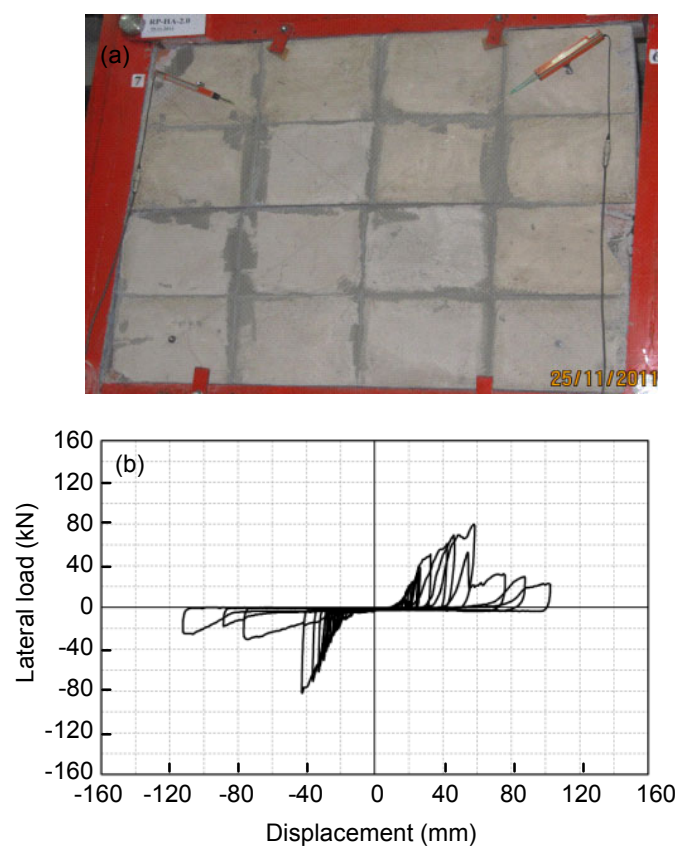

Fig. 5 Photograph after test (a) and load-displacement graph (b) of RP-MA-2.0
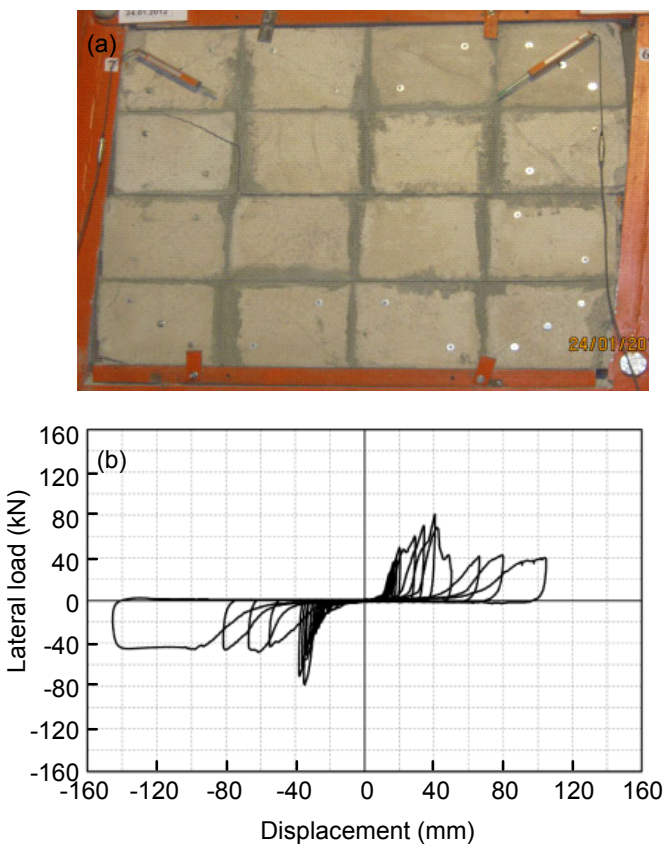

Fig. 7 Photograph after test (a) and load-displacement graph (b) of RP-SA-2.5

of both tests, tile adhesive bonding plates to mortar coat separated from the hollow bricks and plates fell off, most probably stemming from the ineffective bonding of mortar coat to hollow bricks. Mortar coat-hollow brick separation was observed especially
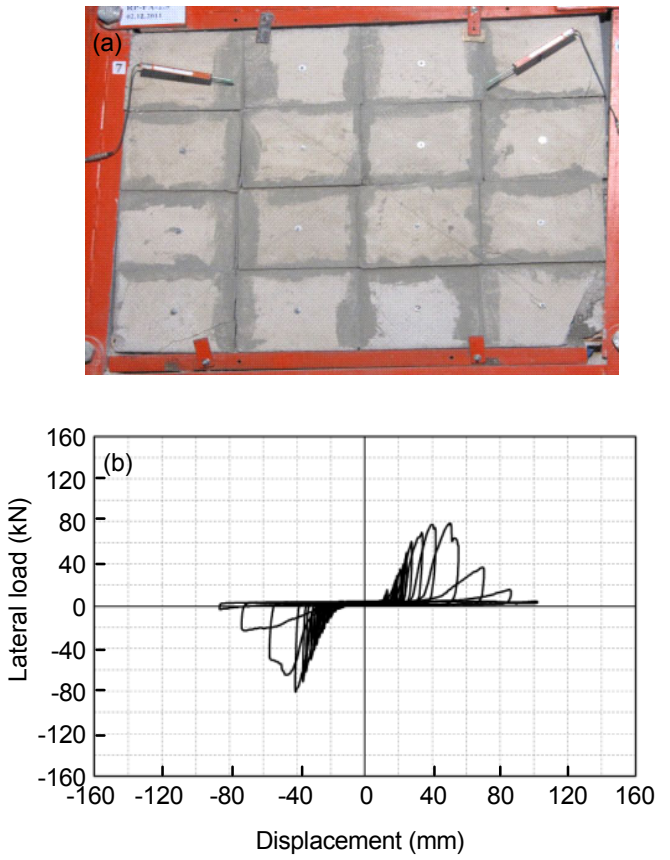

Fig. 6 Photograph after test (a) and load-displacement graph (b) of RP-SA-2.0
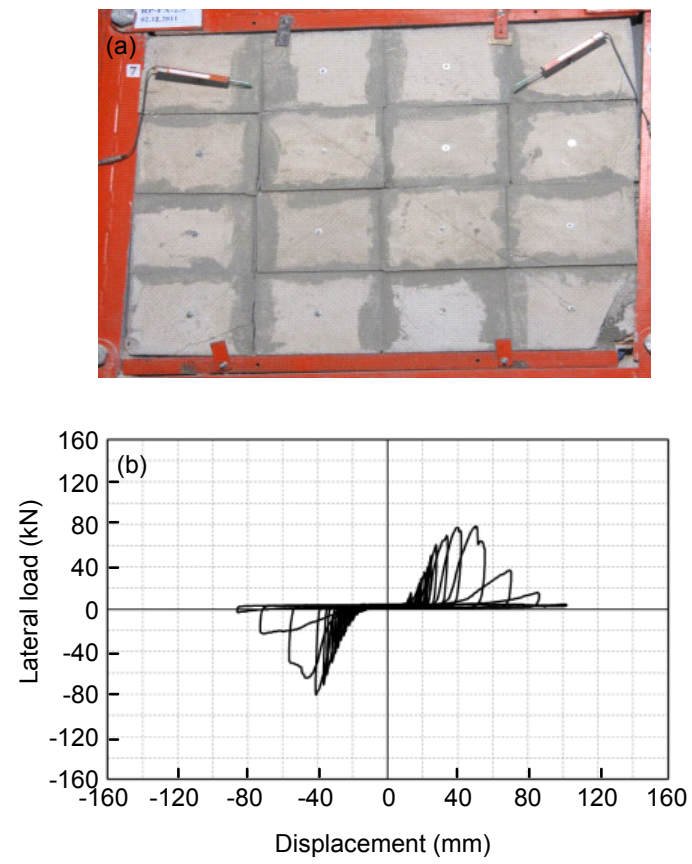

Fig. 8 Photograph after test (a) and load-displacement graph (b) of RP-FA-2.5

in the middle region of the infill of SP-HA-2.0 as shown in Fig. 9. Load-displacement graphs and photographs at the end of the tests of SP-HA-2.0 and SP-HA-2.5 are given in Fig. 9 and Fig. 10, respectively. 

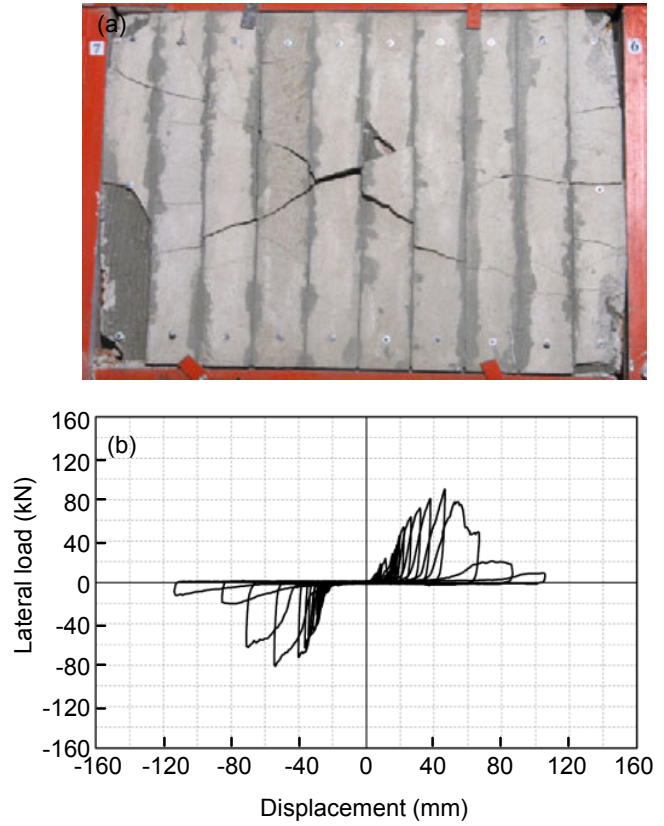

Fig. 9 Photograph after test (a) and load-displacement graph (b) of SP-HA-2.0
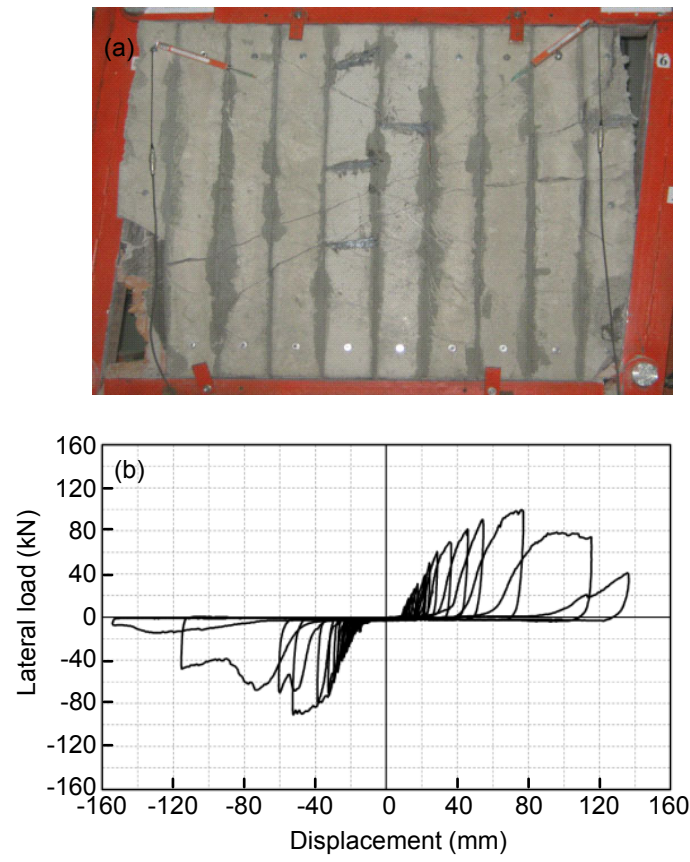

Fig. 10 Photograph after test (a) and load-displacement graph (b) of SP-HA-2.5

Since all the corner plates of previously tested specimens suffered excessive damage due to crushing by rigid steel frame members, test specimens SPR-MA-2.0 and SPR-HA-2.0 were strengthened by $20 \mathrm{~mm}$ thick concrete plates reinforced by $\Phi 2 / 25$ welded wire mesh. Additionally, 2- $\Phi 5$ longitudinal reinforcements were used at each side of all plates in specimen SPR-HA-2.0. Specimen SPR-MA-2.0 reached a lateral load carrying capacity of $71.4 \mathrm{kN}$ at a displacement level of $61.2 \mathrm{~mm}$ in the twelfth forward cycle whereas these values were $102.7 \mathrm{kN}$ and $70.6 \mathrm{~mm}$ in the fifteenth backward cycle for specimen SPR-HA-2.0. Up to further cycles, only hairline cracks were observed whereas corner plates were crushed by rigid steel frame members. In the test of SPR-MA-2.0, separation of plates from the mortar coat was not observed in early cycles. However, hollow bricks at both corner rows crushed and fell off since there were very few bolts for holding them in place where corner plates suffered less damage as compared to previously tested pairs with unreinforced plates. This phenomenon was observed later and less so in the test of SPR-HA-2.0. Load-displacement graphs and photographs at the end of the tests of SPR-MA-2.0 and SPR-HA-2.0 are given in Fig. 11 and Fig. 12, respectively.

Test specimens SPR-HA-2.5 and SPR-FA-2.5 were strengthened by $25 \mathrm{~mm}$ thick concrete plates reinforced by $\Phi 2 / 25$ welded wire mesh. Additionally, 2-Ф5 longitudinal reinforcements were used at each side of all plates in specimen SPR-FA-2.5. They reached lateral load capacities of $130.5 \mathrm{kN}$ and $133.2 \mathrm{kN}$ in the seventeenth and eighteenth forward cycles where displacement levels were $62.2 \mathrm{~mm}$ and $63.5 \mathrm{~mm}$, respectively. Cracks were distributed through all the infill wall and they were not widened till the end of both tests. Relatively small crashes occurred in the corner plates. With the start of decrease in load capacity and stiffness, both tests were terminated. In both tests, separation between plates and mortar coat in addition to crushing followed by falling of hollow bricks was not observed. Loaddisplacement graphs and photographs at the end of the tests of SPR-HA-2.5 and SPR-FA-2.5 are given in Fig. 13 and Fig. 14, respectively.

Test specimens SPR-HA-2.0D and SPR-FA$2.0 \mathrm{D}$ were strengthened by $20 \mathrm{~mm}$ thick concrete plates and reinforced by $\Phi 2 / 25$ welded wire mesh, at both sides of the infill. Specimen SPR-HA-2.0D reached a lateral load carrying capacity of $148.4 \mathrm{kN}$ at a displacement level of $81.7 \mathrm{~mm}$ in the seventeenth forward cycle whereas these values were $157.5 \mathrm{kN}$ and $74.0 \mathrm{~mm}$ in the fourteenth backward cycle for specimen SPR-FA-2.0D. Micro cracks were observed 

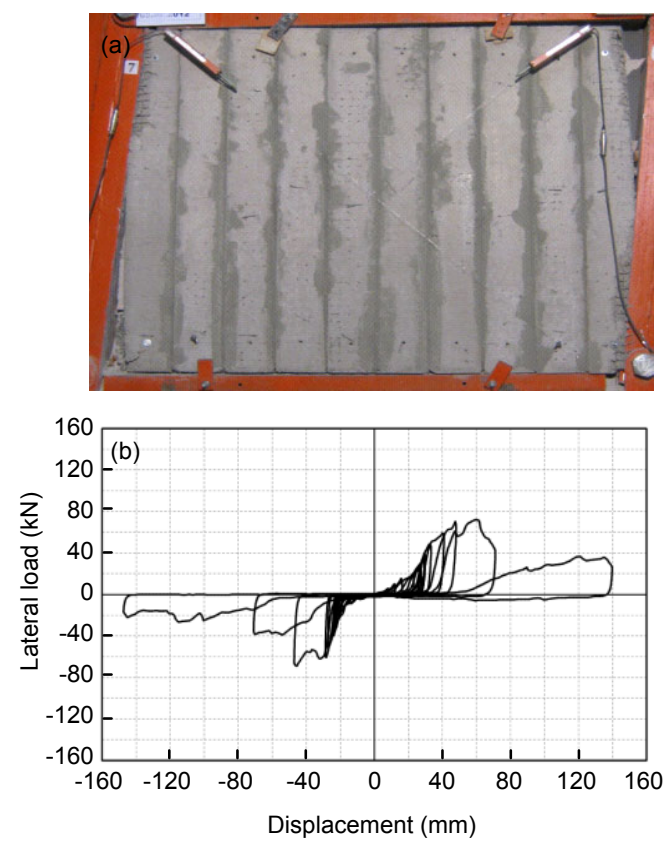

Fig. 11 Photograph after test (a) and load-displacement graph (b) of SPR-MA-2.0
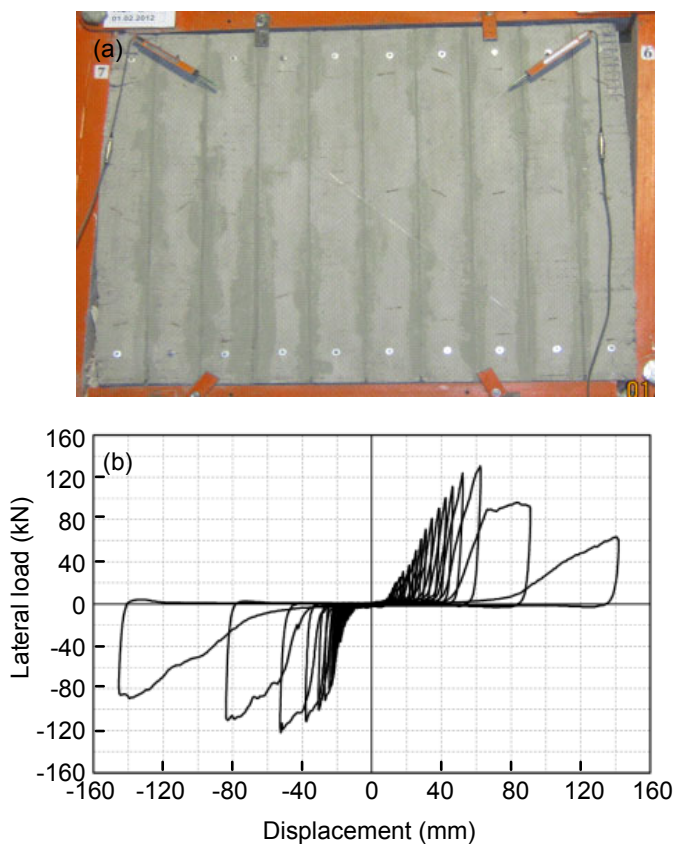

Fig. 13 Photograph after test (a) and load-displacement graph (b) of SPR-HA-2.5

both on the front and back infill walls during both tests and they were not widened until the end of the tests. Relatively small crashes occurred in the corner plates through the end of both tests. Both infill walls
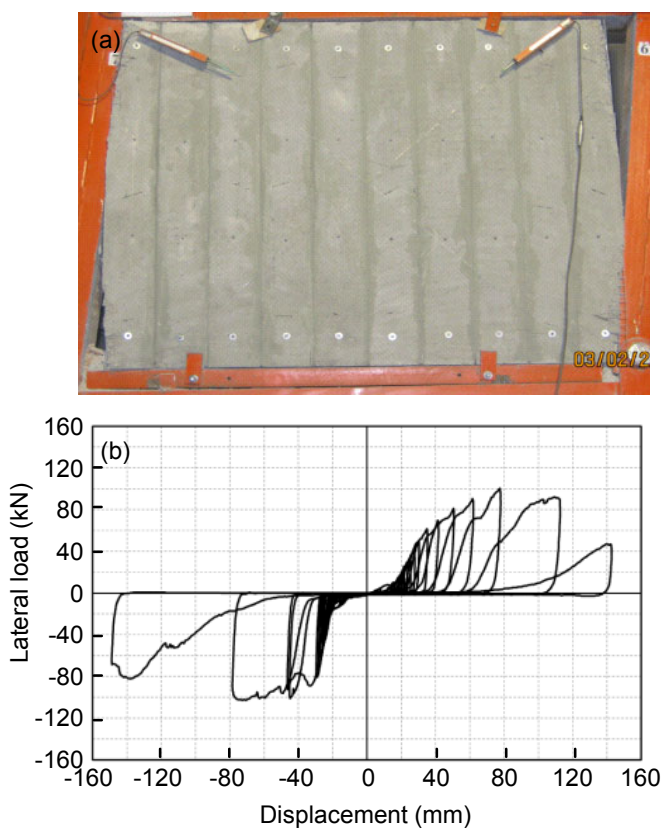

Fig. 12 Photograph after test (a) and load-displacement graph (b) of SPR-HA-2.0
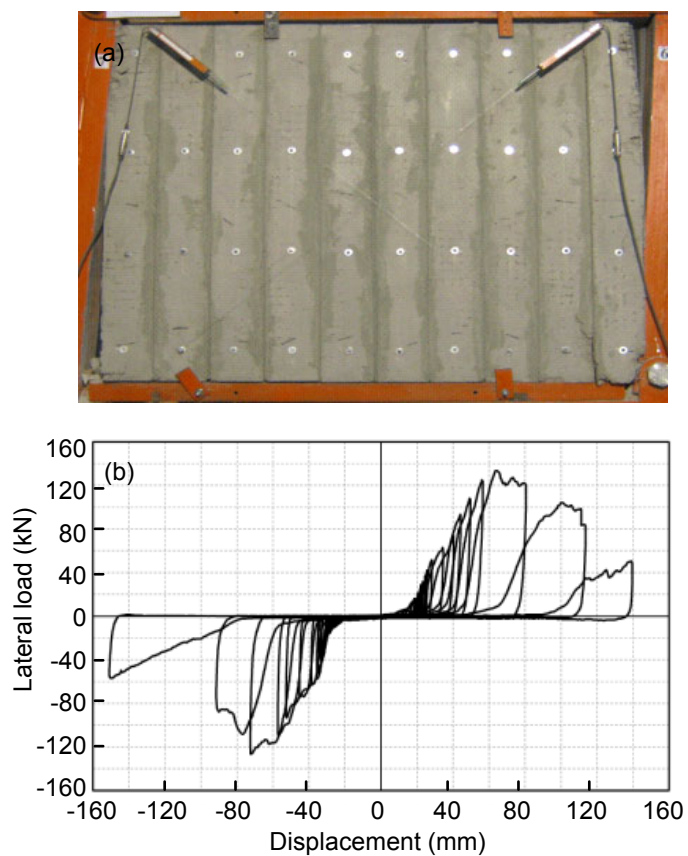

Fig. 14 Photograph after test (a) and load-displacement graph (b) of SPR-FA-2.5

preserved their monolithic forms. Load-displacement graphs and photographs at the end of the tests of SPR-HA-2.0D and SPR-FA-2.0D are given in Fig. 15 and Fig. 16, respectively. 


\section{Discussion}

\subsection{Strength and stiffness}

Performances of test specimens are evaluated in terms of load-top displacement, energy dissipation, initial stiffness, and ductility values as summarized in Table 2. Before the discussion, there is an important point to be mentioned here that there exists a region with zero stiffness in all load-displacement curves. This phenomenon stemmed from two possibilities:
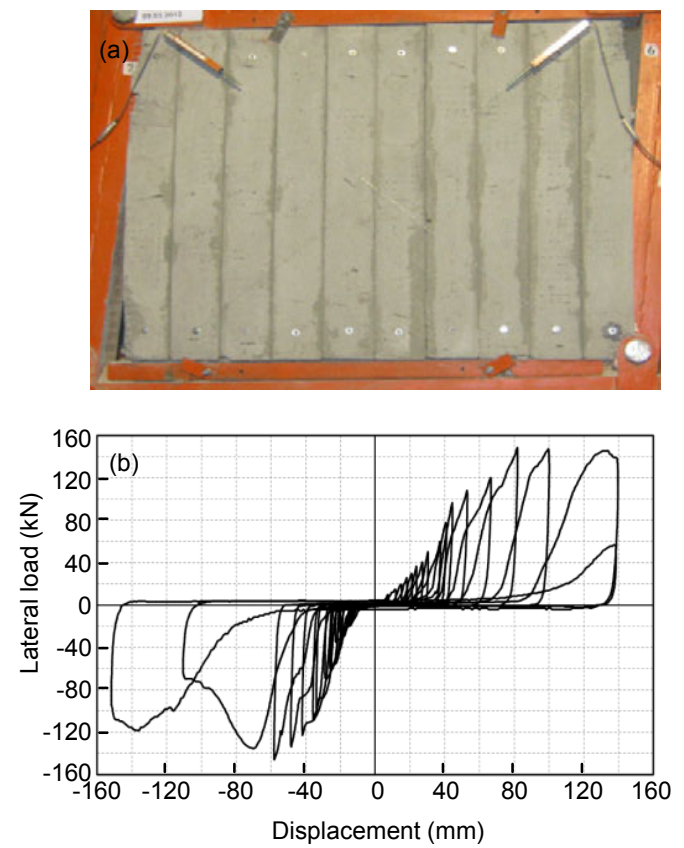

Fig. 15 Photograph after test (a) and load-displacement graph (b) of SPR-HA-2.0D primarily from the damaging of the test specimen corners by much more rigid steel frame members especially in the proceeding cycles, and secondarily from lashes at the joints of the steel frame. These regions of the graphs were taken into account, especially in stiffness and ductility calculations.

When the results in Table 2 are examined, specimens strengthened by strip-shaped plates carried more lateral loads than the specimens strengthened by rectangular ones, except from specimen SPR-MA-2.0.
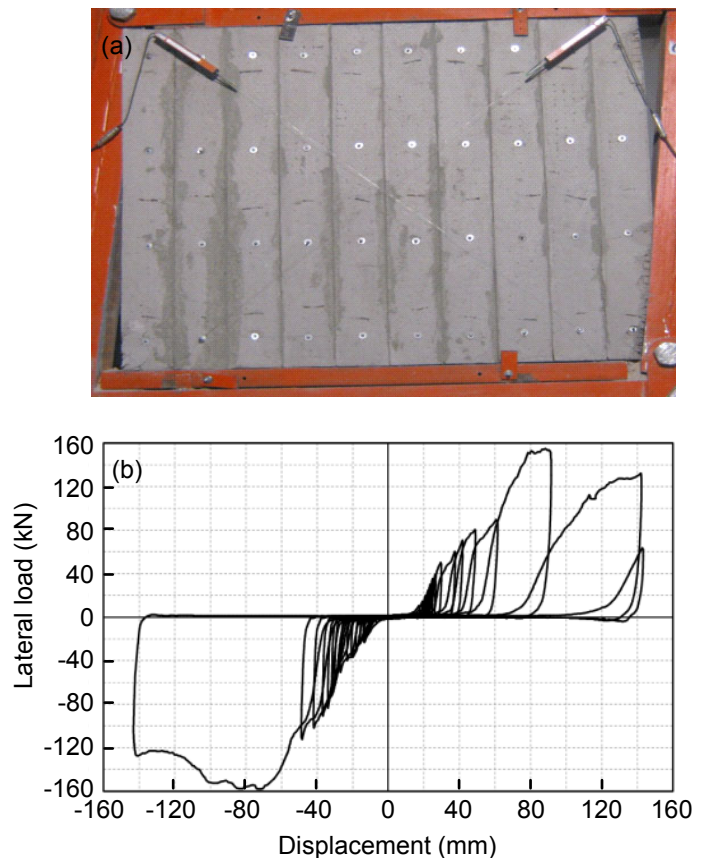

Fig. 16 Photograph after test (a) and load-displacement graph (b) of SPR-FA-2.0D

Table 2 Performance indicators of test specimens

\begin{tabular}{lcccccc}
\hline \multicolumn{1}{c}{ Test specimen } & $\begin{array}{c}\text { Max. forward } \\
\text { lateral load }(\mathrm{kN})\end{array}$ & Ratio $^{*}$ & $\begin{array}{c}\text { Drift ratio } \\
\text { at peak, } \delta / h(\%)\end{array}$ & $\begin{array}{c}\text { Initial stiffness } \\
(\mathrm{kN} / \mathrm{mm})\end{array}$ & $\begin{array}{c}\text { Energy } \\
\text { dissipation }(\mathrm{kJ})\end{array}$ & Ductility \\
\hline Reference & 53.4 & 1.00 & 3.49 & 2.30 & 6.8 & 1.10 \\
RP-MA-2.0 & 79.8 & 1.49 & 3.86 & 2.55 & 10.8 & 1.30 \\
RP-SA-2.0 & 78.7 & 1.47 & 3.15 & 2.90 & 15.5 & 1.48 \\
RP-SA-2.5 & 80.7 & 1.51 & 2.71 & 3.00 & 14.3 & 1.27 \\
RP-FA-2.5 & 78.1 & 1.46 & 3.38 & 2.70 & 9.4 & 1.61 \\
SP-HA-2.0 & 90.0 & 1.69 & 3.09 & 2.50 & 11.5 & 1.51 \\
SPR-MA-2.0 & 71.4 & 1.34 & 4.08 & 4.00 & 12.9 & 1.66 \\
SPR-HA-2.0 & 100.5 & 1.88 & 5.17 & 3.20 & 23.7 & 2.11 \\
SP-HA-2.5 & 99.6 & 1.87 & 5.08 & 3.70 & 19.5 & 1.81 \\
SPR-HA-2.5 & 130.5 & 2.44 & 4.15 & 3.40 & 25.1 & 1.46 \\
SPR-FA-2.5 & 133.2 & 2.49 & 4.23 & 3.45 & 26.0 & 1.61 \\
SPR-HA-2.0D & 148.4 & 2.78 & 5.45 & 4.80 & 38.9 & 1.98 \\
SPR-FA-2.0D & 154.0 & 2.88 & 5.33 & 5.20 & 34.3 & 1.78 \\
\hline
\end{tabular}

* The ratio of maximum lateral load to that of the reference 
This can be owing to the less number of bolts used and relatively low compressive strength of plates which led to early crushing of corner plates. In addition, all specimens strengthened by rectangular shaped plates carried lateral loads of close values. Saw type bolts used in specimens RP-SA-2.0 and RP-SA-2.5 did not bring any extra contribution to lateral load carrying capacity, but nevertheless brought extra workmanship. The increase in lateral load carrying capacity of the strengthened specimens came out to be nearly 1.50 times for rectangular shaped plates.

Unlike the other specimens, SPR-HA-2.0D and
SPR-FA-2.0D were strengthened by bonding precast plates on to only one side of the infill walls. Both specimens exhibited superior behaviour especially when compared to the reference specimen. The increase was nearly 2.80 times for both specimens. Bonding plates on both sides increased lateral load carrying capacity nearly $50 \%$ in the case of specimen SPR-HA-2.0D as compared to SPR-HA-2.0. The increase was nearly the same for the case of specimen SPR-FA-2.0D, but a little higher as expected.

The load history graphs of all test specimens are given in Fig. 17. The increase in strength after
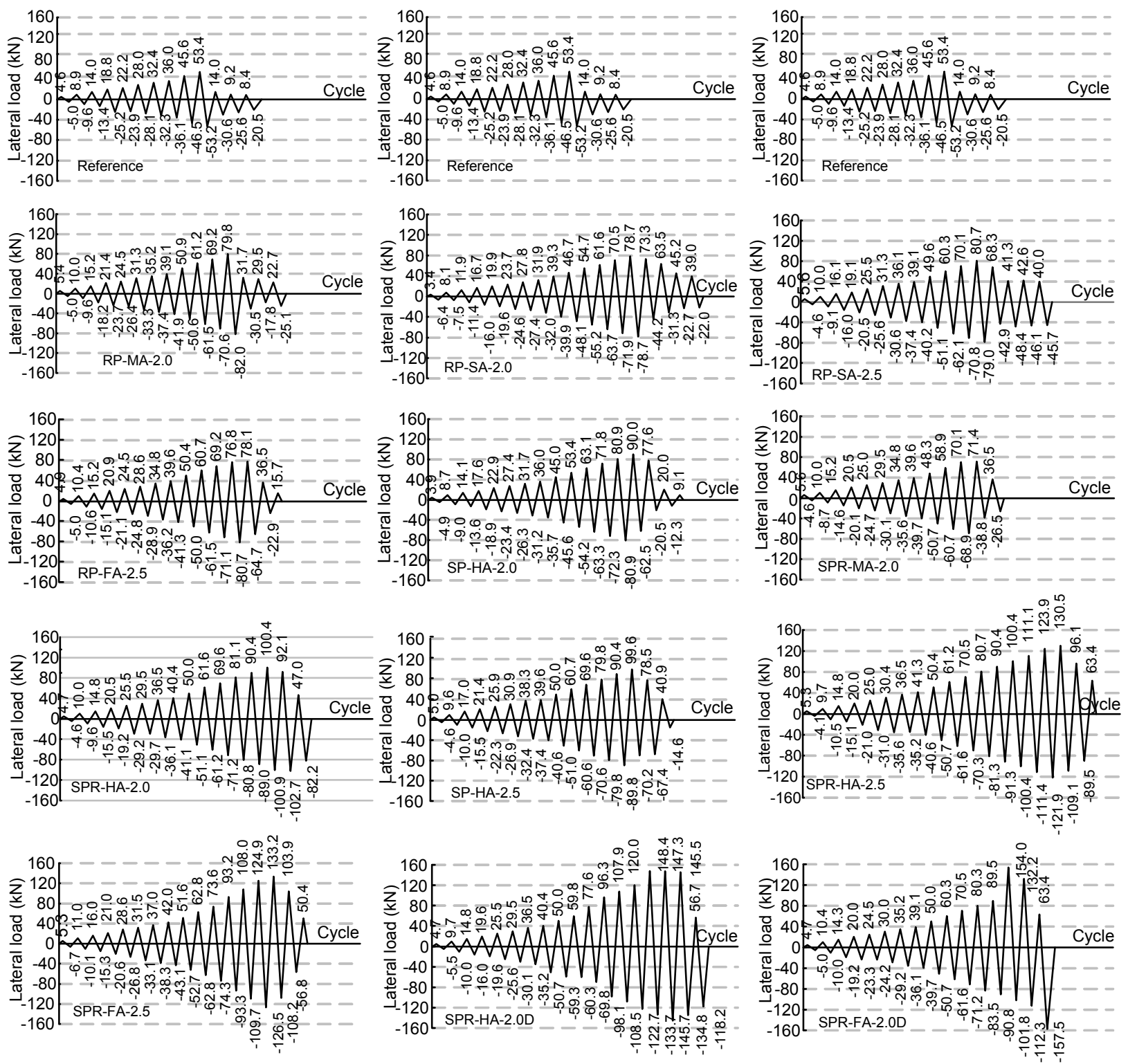

Fig. 17 Load history graphs of all specimens 
bonding precast plates on to mortar coated hollow brick infill walls by ordinary tile adhesive and fixed by $\Phi 6$ bolts can also easily be observed in the curves.

Regarding plate attachment, using more bolts obviously increased the lateral load carrying capacity. However, the increase was very low as compared to plate shape or plate thickness parameters. The relative increase was superior in the case of the SPR-MA-2.0 and SPR-FA-2.0 pair; however, note that the performance of specimen SPR-MA-2.0 was much lower than its expected behaviour as explained before. Thus, the performance of SPR-HA-2.0 was normal from the bolt number point of view.

Strength and stiffness characteristics together with the general behaviour of specimens are evaluated by the help of response-envelope curves as shown in Fig. 18, which were constructed by connecting the peak points of each forward and backward cycles of the lateral load-lateral displacement curves. Corresponding story drift ratios are also given on the same graph. "Story drift index" can be defined as the relative displacement between two successive floors of a reinforced concrete frame divided by the story height. These curves indicate that fixing of precast plates on to the hollow brick infills significantly increase lateral load carrying capacity and stiffness and improve ductility of infill wall specimens. Up to $3.33 \%$ drift ratio, almost all specimens preserved their load carrying capacities. In addition, most of the test specimens reached $4.00 \%$ drift ratio preserving their monolithic forms with minor cracks, which is defined as the collapse prevention limit by Turkish Seismic Code (TSC, 2007).

The initial stiffness values of specimens are given in Table 2. The initial stiffness of a specimen was calculated using the slope of the linear part of the first forward load. The value was used as a relative indicator of improvement of the rigidities of test specimens. As shown Table 2, plates increased the initial stiffness values of specimens. The increase ranged from 1.08 to 2.26 times that of the reference specimen can be owing to the quality of the workmanship in the construction of the hollow brick infill wall, mortar coating of the specimen and bonding of plates, which played an important role in the displacement history in early cycles.

As an indicator of stiffness, tangent slopes of load-displacement curves during forward loading were taken for all cycles. By plotting the stiffness value in each cycle, the stiffness degradation curve of a specimen is obtained. This approach can be considered acceptable since evaluation of the relative values rather than the absolute values is essential. Stiffness degradation curves of all specimens are given in Fig. 19 with the same scale. For all specimens, after a gradual decrease in stiffness in the first few cycles, the conservation of stiffness up to the end shows the effectiveness of the proposed technique.

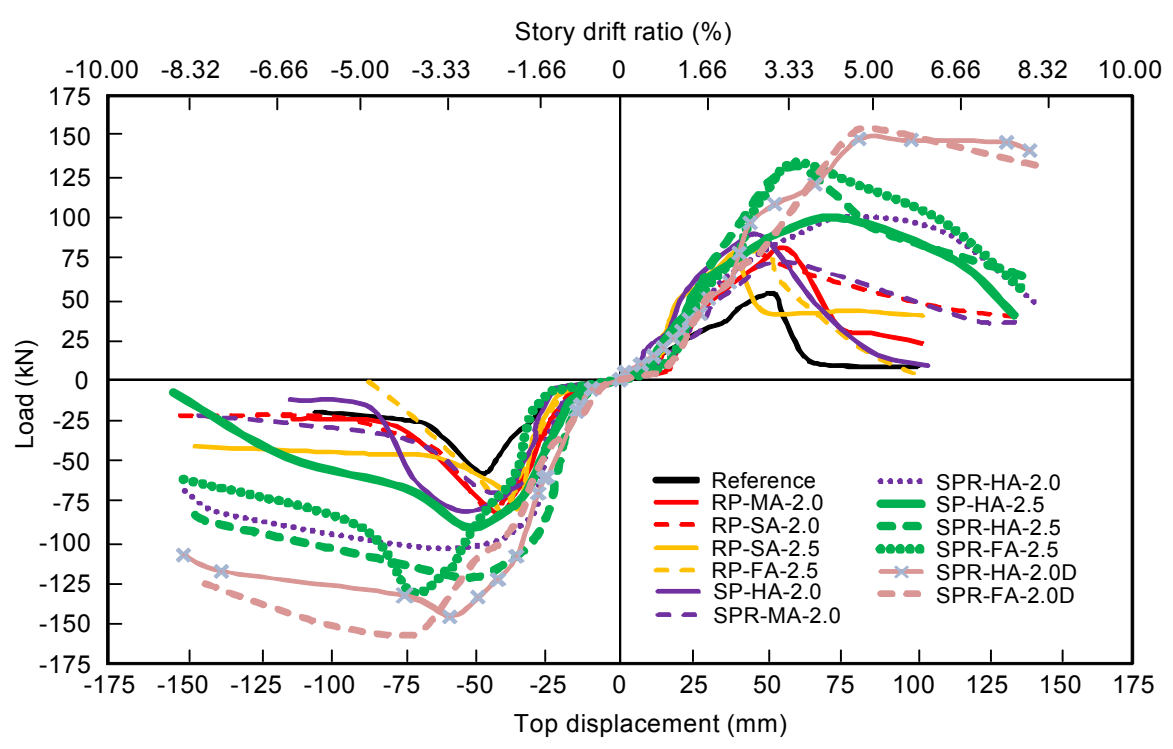

Fig. 18 Response envelope curves of all specimens 

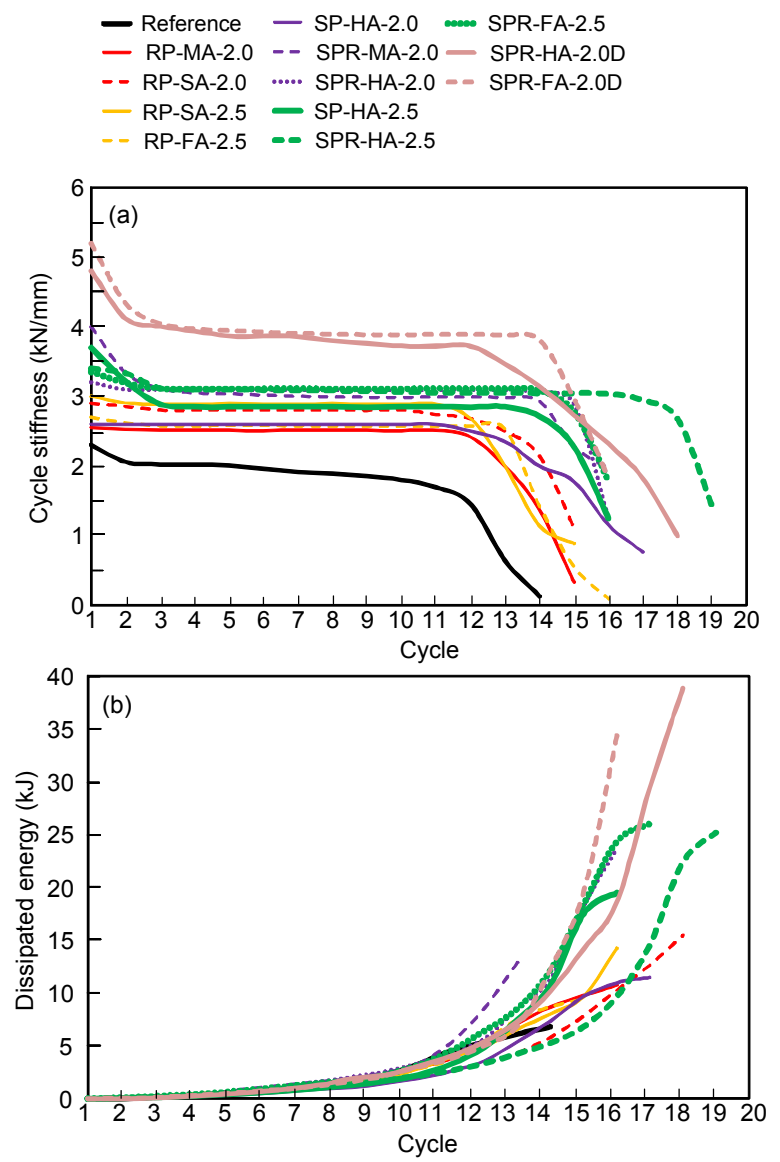

Fig. 19 Stiffness degradation (a) and energy dissipation curves (b) of all specimens

\subsection{Energy dissipation capacities}

Improving the energy dissipation capacity of a specimen is one of the major aims of the strengthening technique. It is also an important indicator of the improved seismic behaviour. It can be determined from the area enclosed by the hysteretic loops of the load-displacement curves. Note that the energy dissipation characteristics of the test specimens strongly depend on the loading history. The loading histories of the specimens, given in Fig. 17, were intended to be the same, but when the response of a test specimen became non-linear, backward and forward half cycle loadings were controlled by lateral displacements. The same lateral displacements were intended to be reached for the forward and backward half cycles.

Cumulative dissipated energy curves of all specimens are given in Fig. 19. All curves follow a relatively linear trend showing linear action until the slope suddenly changes. Start of increased dissipation rate marks the point where plastification starts. Higher curves mean higher energy dissipation.
The total amount of dissipated energy of each specimen is tabulated in Table 2. The energy dissipation capacities of the strengthened specimens increased between 1.38 and 5.71 times. This means that the proposed technique improves the energy dissipation characteristics of the test specimens. Note that specimen RP-FA-2.5 dissipated less energy as compared to the remaining strengthened specimens. This unexpected behaviour can be attributed to several reasons, such as fewer number of inelastic displacement cycles with larger amplitude and/or less lateral load carrying capacities. Brittle behaviour of this specimen can also be observed in Fig. 18. This specimen had a relatively narrow curve especially in the inelastic range.

\subsection{Ductility comparisons}

Displacement ductility is defined by the ratio of the ultimate displacement to yield displacement. The ultimate displacement is defined as the displacement at which the lateral load dropped to $85 \%$ of the maximum applied load at post peak region. The yield displacement was described with a secant drawn starting from the origin and passing through the point on which lateral load is $70 \%$ of the maximum applied load. This secant line was extended up to the horizontal line drawn from the maximum load, and the corresponding displacement was accepted as yield displacement (Baran, 2012). The calculated ductility values are listed in Table 2 .

\subsection{Shear deformations on infills and plates}

Lateral load-infill wall shear displacement curves of all specimens are presented in Fig. 20. As shown in this figure, there was a visible shear deformation on the infill of the reference specimen. After introducing plates, shear deformation due to base shear reduced on plates. All plates behaved rigidly so that they prevented excessive shear deformations. Less shear deformations occurred in specimens strengthened by strip plates compared to rectangular plates, as expected. In the tests of specimens with rectangular plates, horizontal slippages of plates of neighbour rows were observed especially towards the end of the tests where plate bonding lost its effectiveness. This phenomenon increased shear deformations in specimens strengthened by rectangular plates, where plates preserved their monolithic form in specimens with strip plates. 

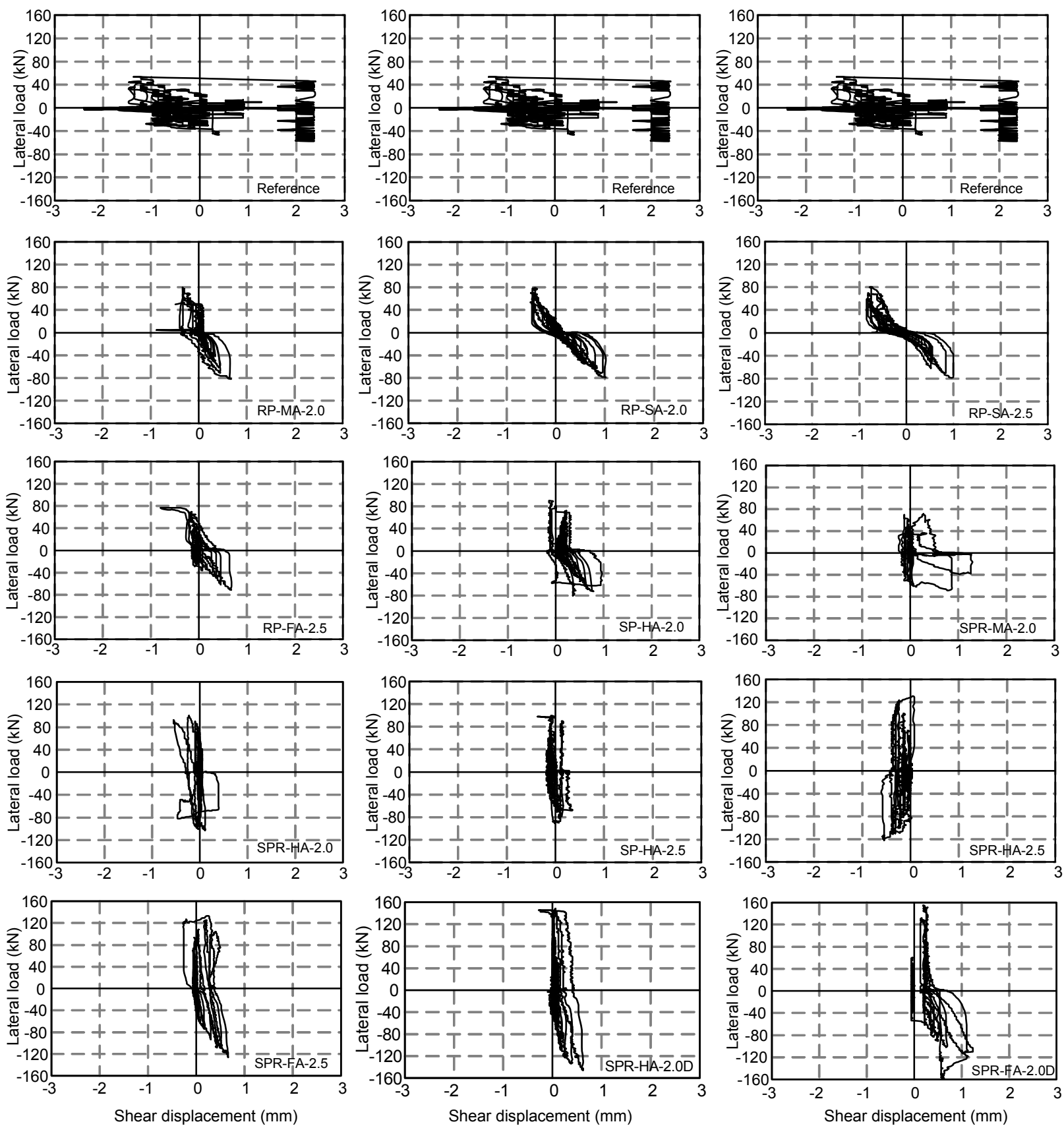

Fig. 20 Shear displacement curves of all specimens

\subsection{Comparison of analytical and experimental results}

In the analytical studies, mortar coated hollow brick infill walls and precast plates were modeled by means of two separate diagonal compression struts as elastic-brittle bars with no tensile resistance
(El-Dakhakhni et al., 2003; Baran et al., 2010). It is assumed that both struts are pin-connected to the frame on both sides. Axial load carrying capacity of the first strut modeling the mortar coated hollow brick infill wall can be calculated by

$$
F_{1}=a_{1} b_{1} f_{\text {infill- } \theta},
$$


where $a_{1}$ is the width of the strut using equations given in Chapter 8.3.1 of Federal Emergency Management Agency (FEMA, 1998), and $b_{1}$ is the thickness that can be taken as the real thickness of the mortar coated hollow brick infill wall $(115 \mathrm{~mm})$. Compressional strength of the mortar coated hollow brick infill wall in the diagonal direction, $f_{\text {infill }-\theta}$, can be calculated by (Baran, 2012)

$$
f_{\text {infill }-\theta}=0.5\left(f_{\text {infill- } 90}+f_{\text {infill-0 }}\right) \text {, }
$$

where $f_{\text {infill }-\theta}$ and $f_{\text {infill- } 0}$ are the compressional strengths of the mortar coated hollow brick infill wall in the vertical and horizontal directions, respectively. Both can be computed using Eq. (3) taking into account the specifications in the loaded direction:

$$
f_{\text {infill }}=\frac{\left(f_{\text {brick }} t_{\text {brick }}+f_{\text {plaster }} t_{\text {plaster }}\right)}{\left(t_{\text {brick }}+t_{\text {plaster }}\right)},
$$

where $f_{\text {brick }}$ is the compressional strength of the hollow brick in the direction of loading, and $f_{\text {plaster }}$ is the compressional strength of the mortar coating. In addition, $t_{\text {brick }}$ and $t_{\text {plaster }}$ are the thicknesses of the hollow brick and mortar coating, respectively. It is assumed that plates will be in monolithic and homogeneous form. Axial load carrying capacity of the second strut modeling the plates bonded on to the wall can be obtained:

$$
F_{2}=a_{2} b_{2} \Phi \times\left(\frac{n_{\mathrm{b}}}{40} \times f_{\text {plate }}\right)^{0.25},
$$

where $a_{2}$ is the width of the second compression strut and computed using equations proposed by Smith $(1962 ; 1966 ; 1967 ; 1968)$ and Smith and Carter (1969), $b_{2}$ is the strut thickness (taken as the real thickness of the plates). Being a constant, $\Phi$, was determined from the push-over curves (displacement controlled type) of the test specimens and taken as 12.0 and 15.0 for one-sided plain concrete and reinforced concrete plates, respectively. For specimens with plates bonded on both sides, it was taken as 25.0. In addition, $n_{\mathrm{b}}$ is the number of $\Phi 6$ bolts, and $f_{\text {plate }}$ is the compressional strength of plates used to strengthen the test specimen.

As a summary, as two equivalent compression struts are used in the analytical studies, axial load carrying capacity of the strengthened infill wall can be computed by

$$
F=F_{1}+F_{2}
$$

In the analytical studies, instead of modeling of the whole behaviour, the aim was to predict lateral load capacity of the strengthened specimen within a certain closeness. Analytical and experimental results are compared in Table 3. Experimental load capacities of the specimens were calculated with $\pm 10 \%$ closeness, except from specimens strengthened by rectangular plates (Table 3).

Table 3 Comparison of experimental data with analytical data

\begin{tabular}{lccc}
\hline \multirow{2}{*}{$\begin{array}{c}\text { Test } \\
\text { specimen }\end{array}$} & \multicolumn{2}{c}{ Lateral load capacity $(\mathrm{kN})$} & \multirow{2}{*}{ Ratio } \\
\cline { 2 - 3 } & Experimental & Analytical & \\
\hline Reference & 53.4 & 52.9 & 0.99 \\
RP-MA-2.0 & 82.0 & 81.5 & 0.99 \\
RP-SA-2.0 & 78.7 & 94.2 & 1.20 \\
RP-SA-2.5 & 80.7 & 108.2 & 1.34 \\
RP-FA-2.5 & 80.7 & 105.9 & 1.31 \\
SPR-HA-2.0D & 148.4 & 144.2 & 0.97 \\
SPR-FA-2.0D & 157.5 & 163.2 & 1.04 \\
SP-HA-2.0 & 90.0 & 86.5 & 0.96 \\
SPR-MA-2.0 & 71.4 & 78.6 & 1.10 \\
SPR-HA-2.0 & 100.4 & 110.5 & 1.10 \\
SP-HA-2.5 & 99.6 & 94.0 & 0.94 \\
SPR-HA-2.5 & 130.5 & 117.2 & 0.90 \\
SPR-FA-2.5 & 133.2 & 120.0 & 0.90 \\
\hline
\end{tabular}

\section{Conclusions}

Based on the limited data obtained from 13 hollow brick infill wall tests and analytical studies conducted, conclusions can be drawn as follows.

1. Bonding precast plates on to mortar coated hollow brick infill walls by ordinary tile adhesive and fixing by $\Phi 6$ bolts increased load carrying capacity and stiffness of the infill walls and improved the behaviour.

2. Lateral load capacity of the specimens strengthened by rectangular plates increased nearly 1.50 times. This value was higher than 1.50 times for almost all specimens strengthened by strip plates. Better results were also obtained for strip plates from 
stiffness, energy dissipation capacity, and ductility points of view.

3. Strengthening infill walls with reinforced plates yielded better results with more improved behaviour. Adding reinforcement with/without extra corner bars delayed early crushing of corner plates.

4. The number of bolts (Ф6) should be optimized for both types of plates since less number of bolts seems to be advantageous with less workmanship. However, walls with less bolts suffered earlier falling of hollow bricks whereas fixing too many bolts increased workmanship with no extra contribution to load capacity. Indeed, too many anchorage holes for bolts damaged the weak infills with ordinary workmanship. Using bolts on all surrounding rectangular plates adjacent to frame members and two rows of bolts (top and bottom for each plate) for strip plates seems to be appropriate.

5. Story drift ratios did not exceed the values identified by the Turkish Seismic Code (TSC, 2007). Plate strengthened infill walls will obviously be in monolithic form until the collapse prevention limit which is defined as $4.00 \%$ by Turkish Seismic Code (TSC, 2007).

6. Ductility of all strengthened specimens increased as compared to the reference specimen. Generally, strengthening by thinner RC plates gave results in more favour of ductility. The increase in ductility ranged from 1.27 times to 2.11 times.

7. Domestic, cheap, and readily available materials were used in the proposed strengthening technique which means that the technique is economic as well as occupant friendly. Evacuation of the building will be unnecessary during application of the technique.

8. In previous studies (Baran et al., 2010; Baran and Tankut, 2011a; 2011b), plates were bonded on to the mortar coated hollow brick infill walls using an effective but at the same time an expensive import material. Although the tile adhesive for bonding of plates showed unspectacular bonding performance as compared to this material, it will obviously make the technique more economical which is one of the most important criterion in application. This phenomenon, which seems to be disadvantageous, can be underrated by fixing plates on to slightly increased number of infill walls required to be strengthened.

9. Hollow brick infills strengthened by precast plates were modeled by equivalent diagonal com- pression struts. Here, the aim is to propose simple methods estimating ultimate loads of the strengthened specimens within acceptable closeness. In this study, load capacities were calculated with $\pm 10 \%$ closeness for specimens strengthened with strip plates.

\section{Acknowledgements}

The authors gratefully acknowledge the supports of Assoc. Prof. Dr. Sabahattin Aykaç and Assoc. Prof. Dr. Serkan Tapkın, Turkey.

\section{References}

Acun, B., Sucuoğlu, H., 2005. Tuğla Dolgu Duvarlı Çerçevelerin Hasır Donatı Ile Güçlendirilmesi. Earthquake Symposium, Kocaeli, Turkey, p.965-971 (in Turkish).

Alcocer, S.M., Ruiz, J., Pineda, J.A., Zepeda, J.A., 1996. Retrofitting of Confined Masonry Walls with Welded Wire Mesh. 11th World Conference on Earthquake Engineering, Acapulco, Mexico, p.1471.

Altın, S., Anıl, Ö., Kara, M.E., Kaya, M., 2008. An experimental study on strengthening of masonry infilled RC frames using diagonal CFRP strips. Composites Part B: Engineering, 39(4):680-693. [doi:10.1016/j.compositesb. 2007.06.001]

Amanat, K.M., Alam, M.M.M., Alam, M.S., 2007. Experimental investigation of the use of ferrocement laminates for repairing masonry in filled RC frames. Journal of Civil Engineering (IEB), 35(2):71-80.

Antoniades, K.K., Salonikios, T.N., Kappos, A.J., 2005. Tests on seismically damaged reinforced concrete walls repaired and strengthened using fiber-reinforced polymers. Journal of Composites for Construction, 9(3):236-246. [doi:10.1061/(ASCE)1090-0268(2005)9:3(236)]

Baran, M., 2012. Investigation of the effects of infill walls on the behaviors of reinforced concrete framed structures. Journal of the Faculty of Engineering and Architecture of Gazi University, 27(2):275-284.

Baran, M., Tankut, T., 2011a. Experimental study on seismic strengthening of reinforced concrete frames by precast concrete panels. ACI Structural Journal, 108(2):227-237.

Baran, M., Tankut, T., 2011b. Retrofit of non-ductile RC frames with precast concrete (PC) wall panels. Advances in Structural Engineering, 14(6):1149-1166. [doi:10. 1260/1369-4332.14.6.1149]

Baran, M., Canbay, E., Tankut, T., 2010. Seismic strengthening with precast concrete panels-theoretical approach. Technical Journal, 21(2):4959-4978 (in Turkish).

Binici, B., Özcebe, G., 2006. Seismic Evaluation of Infilled Reinforced Concrete Frames Strengthened with FRPS. Proceedings of the 8th US National Conference on Earthquake Engineering, San Francisco, California, USA, p.1717. 
Canbay, E., Ersoy, U., Ozcebe, G., 2003. Contribution of reinforced concrete infills to seismic behavior of structural systems. ACI Structural Journal, 100(5):637-643.

El-Dakhakhni, W.W., Elgaaly, M., Hamid, A.A., 2003. Threestrut model for concrete masonry-infilled steel frames. Journal of Structural Engineering, 129(2):177-185. [doi:10.1061/(ASCE)0733-9445(2003)129:2(177)]

ElGawady, M., Lestuzzi, P., Badoux, M., 2004. A Review of Conventional Seismic Retrofitting Techniques for URM. 13th International Brick and Block Masonry Conference, Amsterdam, p.10.

Erdem, İ., Akyüz, U., Ersoy, U., Özcebe, G., 2006. An experimental study on two different strengthening techniques for RC frames. Engineering Structures, 28(13): 1843-1851. [doi:10.1016/j.engstruct.2006.03.010]

Farooq, S.H., Ilyas, M., Ghaffar, A., 2006. Technique for strengthening of Masonry wall panels using steel strips. Asian Journal of Civil Engineering (Building and Housing), 7(6):621-638.

FEMA (Federal Emergency Management Agency), 1998. Evaluation of Earthquake Damaged Concrete and Masonry Wall Buildings, FEMA 306.

Frosch, R.J., 1996. Seismic Rehabilitation Using Precast Infill Walls. PhD Thesis, The University of Texas at Austin, Austin, USA.

Frosch, R.J., 1999. Panel connections for precast concrete infill walls. ACI Structural Journal, 96(4):467-472.

Frosch, R.J., Li, W., Jirsa, J.O., Kreger, M.E., 1996a. Retrofit of non-ductile moment-resisting frames using precast infill wall panels. Earthquake Spectra, 12(4):741-760. [doi:10.1193/1.1585908]

Frosch, R.J., Li, W., Kreger, M.E., Jirsa, J.O., 1996b. Seismic Strengthening of a Nonductile RC Frame Using Precast Infill Panels. Eleventh World Conference on Earthquake Engineering, Acapulco, Mexico.

Kahn, L.F., 1984. Shotcrete strengthening of brick masonry walls. ACI Concrete International, 6(7):34-40.

Korkmaz, S.Z., Kamanli, M., Korkmaz, H.H., Donduren, M.S., Cogurcu, M.T., 2010. Experimental study on the behaviour of nonductile infilled RC frames strengthened with external mesh reinforcement and plaster composite. Natural Hazards and Earth System Sciences, 10(11): 2305-2316. [doi:10.5194/nhess-10-2305-2010]

Papanicolaou, C., Triantafillou, T., Lekka, M., 2011. Externally bonded grids as strengthening and seismic retrofitting materials of masonry panels. Construction and Building Materials, 25(2):504-514. [doi:10.1016/j.conbuildmat. 2010.07.018]

Sevil, T., Baran, M., Bilir, T., Canbay, E., 2011. Use of steel fiber reinforced mortar for seismic strengthening. Construction and Building Materials, 25(2):892-899. [doi:10. 1016/j.conbuildmat.2010.06.096]

Smith, B.S., 1962. Lateral stiffness of infilled frames. ASCE Journal of the Structural Division, 88(6):183-199.

Smith, B.S., 1966. Behavior of square infilled frames. ASCE Journal of the Structural Division, 92(ST1):381-403.

Smith, B.S., 1967. Methods for predicting the lateral stiffness and strength of multi-storey infilled frames. Building Science, 2(3):247-257. [doi:10.1016/0007-3628(67) 90027-8]

Smith, B.S., 1968. Model test results of vertical and horizontal loading of infilled frames. ACI Journal Proceedings, 65(8):618-625.

Smith, B.S., Carter, C., 1969. A method of analysis for infilled frames. ICE Proceedings, 44(1):31-48. [doi:10.1680/iicep. 1969.7290]

Sonuvar, M.O., Ozcebe, G., Ersoy, U., 2004. Rehabilitation of reinforced concrete frames with reinforced concrete infills. ACI Structural Journal, 101(4):494-500.

Taghdi, M., Bruneau, M., Saatcioglu, M., 2000a. Analysis and design of low-rise masonry and concrete walls retrofitted using steel strips. Journal of Structural Engineering, 126(9):1026-1032. [doi:10.1061/(ASCE)0733-9445(2000) 126:9(1026)]

Taghdi, M., Bruneau, M., Saatcioglu, M., 2000b. Seismic retrofitting of low-rise masonry and concrete walls using steel strips. Journal of Structural Engineering, 126(9): 1017-1025. [doi:10.1061/(ASCE)0733-9445(2000)126:9 (1017)]

Topçu, İ.B., Işıkdağ, B., Tatar, Ö., Abi, E., 2005. Depremde Hasar Görmüş Binaların Ferrocement Panellerle Güçlendirilmesi. Earthquake Symposium, Kocaeli, Turkey, p.917-926 (in Turkish).

TSC (Turkish Seismic Code), 2007. Ministry of Public Work and Settlement. Government of Republic of Turkey, Ankara.

Turk, A.M., Ersoy, U., Ozcebe, G., 2006. Effect of introducing $\mathrm{RC}$ infill on seismic performance of damaged RC frames. Structural Engineering and Mechanics, 23(5):469-486. [doi:10.12989/sem.2006.23.5.469] 